\title{
Nature-Resource Potential of the Carpathian Region of Ukraine and Specificities of Its Use by Farming Enterprises
}

\author{
Valeriy Rudenko, Myroslav Zayachyk, Mariya Palamaryuk
}

Chernivtsi National University, Chernivtsi, Ukraine.

Email: rudenko_valery@ukr.net, zayachykmyroslav@ukr.net, palamaruk_maria@ukr.net

Received February $13^{\text {th }}, 2013$; revised April 16 ${ }^{\text {th }}, 2013$; accepted April 29 $9^{\text {th }}, 2013$

Copyright (C) 2013 Valeriy Rudenko et al. This is an open access article distributed under the Creative Commons Attribution License, which permits unrestricted use, distribution, and reproduction in any medium, provided the original work is properly cited.

\begin{abstract}
Method of nature-resource potential cost revaluation is suggested. The method proceeds from natural crop yield of Ukrainian lands provided that crops rotation is observed and lands are operated only mechanically with the use of no fertilizer. Nature-resource potential of Ukraine and its Carpathian Region are assessed in the aspect of administrative oblasts. Specificities of nature-resource potential's use by farming enterprises are characterized. Peculiarities that effected upon formation of farming in Ukraine are reviewed. Indices of land availability are presented.
\end{abstract}

Keywords: Ukraine; Nature Resources; Value Assessment; Carpathian Region of Ukraine; Farming Enterprises

\section{Introduction}

A system of national-level accounts has been introduced in Ukraine in accordance with international standards. The system represents total indices of consistent and mutually complimentary description of economics' most important processes and phenomena, i.e., production, income, consumption, and accumulation of capital and finances. Gross domestic product represented on a regional level as gross regional product since 2004, takes the central place in this system.

Proper understanding of nature-resource efficiency in the social-economic development in this or that region requires that the analysis of Ukrainian gross regional product development dynamics and its territorial differentiation were contrasted to assessment indices of nature-resource potential (NRP) of the country's landscape complexes.

Characterized by increase of human-caused load upon nature, exhaustion of many types of nature resources, decrease of human environment quality, the social development of Ukraine and its regions necessitates elaboration of scientifically substantiated system of use of nature-resource potential within the territory. As a parameter that represents the whole totality of nature resources, the nature-resource potential is a pre-condition and a factor for the economy (inclusive of farming eco- nomy) development and functioning, and a basis for rational territorial organization of both nature use and productive forces on the whole.

\section{Aim and Tasks of Investigation}

Represented by combination of mineral, water, land, forest, fauna and natural recreational resources, NRP of the territory is particularly inertial and relatively stable in its quantitative and qualitative development. Accordingly, natural revaluation of major portion of nature resources on a national level is carried out no more than every 10 20 years. The same is true for ecological-economic assessment of the country's NRP components. The last economic appraisal of Ukrainian agricultural lands, for instance, dates back to 1987-1988. Similar situation is with mineral, water and forest resources. On the one hand, this labor-intensive and time-consuming broadscale operation involves vast financial resources; on the other hand, said NRP inertia makes frequent revaluations senseless (for instance, the country's annual average stock of water resources stayed practically unchanged in 1985-1990 and 2005-2010).

Considering the above, Ukrainian geographers engaged in resource studies focus on the problem of indexation of nature resource cadastre assessments made in late 1980s-1990s. 
Our previous 1980-1992 NRP studies were discussed in detail in [1,2], where the value of the country's annualized total nature-resource potential was estimated to amount to 53.95 milliard rubles. It is important to study out the NRP cost measurements in 2006-2010 prices in UAH and USD equivalent; explore the country's present-day nature-resource possibilities on the world market, and its further perspectives for the development of nature use sectors.

To our opinion, land resources as the principal element of national wealth and the key sector of Ukrainian nature-resource complex should be put in the center of the assessment. In the variety of approaches to determine the potential of agricultural lands [3,4], publications by I. R. Yukhnovskyy and G.M. Loboda [5] deserve particular attention. The authors' dominant idea is that "the natural yielding capacity of Ukrainian lands, i.e. such capacity achieved by adhering to crop rotation and to only mechanical soil cultivation with no fertilization should be taken as an assessment standard”.

Total productivity of NRP components is a weighing pre-condition for the economy development. Agricultural and forestry-based nature use predominates in the Carpathian Region of Ukraine being a direct consequence of the availability of significant areas of land and forest resources. The last decades witnessed the private ownership to substitute a sole state-owned land ownership, when considerable land areas were transferred from collective farms (kolkhoz) and state-owned farms (sovkhoz) to individual owners and newly-formed farming enterprises. The present study also aims at the analysis of specificities encountered in the process of use by farming enterprises of the nature-resource potential within the territory of the Carpathian Region.

\section{Research Methods and Areas}

According to the data available with the Soil Science and Agro-Chemistry Institute of the Ukrainian Academy of Sciences, the grains average natural yield capacity in Ukraine amounts to $26 \mathrm{dt} / \mathrm{ha}$, which is a serious evidence of the country's advantages in the world. At the same time, taking into account that the values of average yield capacity in 1995-2000 were lower than those of natural capacity, I.R. Yukhnovskyy and G.M. Loboda suggested that, temporarily and until the yield natural capacity is rehabilitated, the average costs standards be calculated at a level of $21 \mathrm{dt} / \mathrm{ha}$. The authors therewith insist that the value of land tax must not depend on agricultural producer's real income, but be calculated proceeding from normative income, i.e. the one gained in each particular area provided that a certain economy management standard is kept to. This principle will compel agricultural producer to improve the land use practices, since a fixed tax shall be required to be paid regardless of the achieved economic management results [6].

As calculated by scientists of the Soil Science and Agro-Chemistry Institute of the Ukrainian Academy of Sciences [7], average standard cost price of grain in Ukraine amounts to $\$ 62$ per ton, while its cost- to $\$ 97$. Hence, the average standard profit will amount to \$73.5/ ha. Having taken these as the basis, and with the bank interest rate of $23.5 \%$ for deposits to natural persons and with the absolute land rent amounting to \$16/ha, I.R. Yukhnovskyy and G.M. Loboda obtained the normative starting price of arable land to be \$381/ha. At the same time, "considering high interest rate for bank deposits, the average normative land's price in Ukraine in present-day conditions is nearly 10 times lower than its real cost”. That is, the present-day price of arable land is \$3810/ha.

Having considered that the value of 1 ha perennial crop lands is three times higher, and natural forage nearly two times lower than the arable land price, we'll get the normative starting price for the potential of all agricultural lands in the country to be $\$ 159.3$ milliard.

Here we must remember that we speak about the so-called capitalized estimation of the potential of agricultural lands. With Ukrainian economics' average normative coefficient of capital investments' efficiency of 0.15 , the value of land potential in this country in yearly proportion will amount to \$23.9 milliard.

It should be noted that in 1990s we performed calculations of the value of the country's starting nature-resource potential in USD equivalent and found the annual average potential of the country's agricultural lands to be $\$ 24.18$ milliard. And, as it is evident today, the land price according to I.R. Yukhnovskyy and G.M. Loboda practically coincides with our findings. In this case, the scale of comparability of the potential of the country's most important nature resource seems to be very important, since it is the one that allows (to a certain extent) for application of corresponding conversion coefficients so that we could transform Ukrainian NRP value in nature resource prices of 1990s into the same of present day nature use development. We believe that the USD/UAH exchange rate of 1:6.3 could become the coefficient that would help converse nature resource cadastre prices of 1990s into those of present day. Thus, the nature resource potential of Ukraine in yearly proportion and at the present-day level of prices for nature resources amounts to UAH338.39 milliard.

\section{Results}

Table 1 below represents the value and territorial differentiation of the integral nature-resource potential of Ukraine and its Carpathian Region in the aspect of administrative oblasts. Estimation grounds on NRP value data available for 500 administrative rayons of Ukraine [8]. 
Table 1. Nature-resource potential of Ukraine (in prices of 2006-2010).

\begin{tabular}{|c|c|c|c|c|c|c|c|}
\hline \multirow{2}{*}{$\begin{array}{l}\text { Natural region and } \\
\text { administrative oblasts }\end{array}$} & \multicolumn{7}{|c|}{ Value of the potential (UAH milliards/USD milliards) } \\
\hline & Mineral & Water & Land & Forest & Fauna & $\begin{array}{c}\text { Natural } \\
\text { recreational }\end{array}$ & Integral \\
\hline Ukraine & $95.615 / 15.245$ & $44.248 / 7.055$ & $150.192 / 23.946$ & $14.111 / 2.250$ & $1.603 / 0.256$ & $32.623 / 5.201$ & 338.392/53.953 \\
\hline Carpathian Region & $\begin{array}{l}14.532 / \\
2.315\end{array}$ & $32.794 / 5.227$ & $34.604 / 5.516$ & $17.614 / 2.808$ & $0.179 / 0.029$ & $22.687 / 3.616$ & $122.401 / 19.511$ \\
\hline \multicolumn{8}{|c|}{ Inclusive of } \\
\hline Zakarpattia & $0.945 / 0.151$ & $9.723 / 1.550$ & $5.980 / 0.952$ & $5.386 / 0.859$ & $0.025 / 0.004$ & $8.826 / 1.407$ & $30.885 / 4.923$ \\
\hline Ivano-Frankivsk & $2.102 / 0.335$ & $9.444 / 1.505$ & $6.840 / 1.091$ & $4.996 / 0.796$ & $0.038 / 0.006$ & $4.929 / 0.786$ & 28.349/4.519 \\
\hline Lviv & $10.651 / 1.697$ & $10.712 / 1.707$ & $13.813 / 2.203$ & $5.230 / 0.834$ & $0.082 / 0.014$ & $6.744 / 1.074$ & 47.232/7.529 \\
\hline Chernivtsi & $0.825 / 0.132$ & $2.915 / 0.465$ & $7.971 / 1.270$ & $2.002 / 0.319$ & $0.034 / 0.005$ & $2.188 / 0.349$ & $15.935 / 2.540$ \\
\hline
\end{tabular}

Among all nature resources, land resources take the leading role in Ukraine. Lands are the major natural productive force in the Carpathian Ukraine, too, though the region features significant territorial differences conditioned by specificity of orographic composition, bifurcated hydro-net and reforestation of the territory. Besides, demographic factor, namely, high population density and small contour of productive lands are also of considerable effect. This is why land resources in the Zakarpattia and the Ivano-Frankivsk Oblasts miss their headship.

Private land use in Ukraine started its significant development with introduction of the agrarian reform. It was preceded by comparatively big collective and stateowned economies which enjoyed all advantages of huge formations. Hypothetically, broad-scale farming in Ukraine would be possible and appropriate if potential farmers and the state had sufficient finances to develop both farming enterprises of rational size and adequate market environment. Farmer-entrepreneur's formation also takes time. Twenty years of farming in Ukraine are now evidence of a kind of inheritance of farming business. Present-day state of farming in Ukraine is shown in Table 2.

It is agricultural production that is differentiated by territorial diversity of nature-resource potential most essentially, said differentiation conditioning natural productivity of agricultural activity. Nature-resource potential effects upon agricultural production with its whole totality, though the influence of land and water resources is the most fundamental. The Carpathian Region of Ukraine is sufficiently provided with water resources and its hydro-net is rather dense allowing farmers enjoy water stock in full arranging fish farms and irrigating arable crops. Orographic peculiarities of the region and its natural vegetation (natural hayfields and grasslands) are the stimuli to formation of farm economies of stockraising specialization. Land resources in each particular locality determine the focus of arable farming and principal methods of crop cultivation. The major specificity of land use by farming economies is the lands' highest possible involvement into agricultural production (97\% of arable lands in Ukraine are tilled by the farmers). On the whole, $60 \%$ of 2830.3 thousand ha of arable lands available in the Carpathian Region are tilled, whereas the level of tillage in farming economies is $92 \%$. The reason is that the farmers are maximally economically interested to assure for land lease and credit payments. The distribution of land stock in administrative oblasts of the Carpathian Region is presented in Table 3.

The size of farmer's land plot is of peculiar importance in each country. West European experience shows that production is efficient if the area of land use exceeds 100 ha. In fact, average area used by a single farming economy is far from being optimal even in developed states. In particular, small farms prevail in the EC countries: nearly $60 \%$ of all farming enterprises use less than 5 ha of agrarian lands each. The share of such small economies in the totality of EC farms amounts to $78 \%$ in Italy, $76 \%$ in Greece, 58\% in Spain, and 34\% - 35\% in Germany, Austria, Belgium, Netherlands and Finland. In contrast, the share of big economies with average land area of over 100 ha is $27 \%$ in Germany, $16 \%$ in Great Britain, 8\% in France and 2\% in Austria [9].

Scientists representing the Institute of Agrarian Economics at the Ukrainian Academy of Sciences conclude that farms using on the average less than 20 ha of agrarian lands in Ukraine are not rational, and efficient economy management is possible with farms that use over 150 - 200 ha, since cost price of land decreases with the increase of the cultivated land areas [10]. The Carpathian Region features $40 \%$ of farming enterprises that use lands of less than 5 ha, and $6 \%$ of the same using over 100 ha.

The trend of farm quantity reduction with simultaneous insignificant increase of used land areas is today observed in many countries. That is, it is a trend of big investments with simultaneous effort of agrarian lands expansion and formation of farms with developed auxiliary 
Table 2. Farming economies in Ukraine.

\begin{tabular}{|c|c|c|c|c|c|c|}
\hline \multirow{2}{*}{ Years } & \multicolumn{2}{|c|}{ Farming economies } & \multicolumn{2}{|c|}{$\begin{array}{l}\text { Agricultural lands } \\
\text { (thousand ha). }\end{array}$} & \multicolumn{2}{|c|}{$\begin{array}{l}\text { Agricultural lands per } 1 \\
\text { farming enterprise, ha. }\end{array}$} \\
\hline & Total economies & $\begin{array}{l}\text { Inclusive of economies in } \\
\text { the Carpathian Region }\end{array}$ & Total & $\begin{array}{l}\text { Inclusive of lands in the } \\
\text { Carpathian Region }\end{array}$ & Total & $\begin{array}{l}\text { Inclusive of lands in the } \\
\text { Carpathian Region }\end{array}$ \\
\hline 1990 & 82 & 46 & 1.99 & 0.486 & 24.3 & 10.6 \\
\hline 1991 & 2098 & 603 & 39.7 & 4.96 & 18.9 & 8.2 \\
\hline 1992 & 14,681 & 1815 & 292.3 & 13.5 & 19.9 & 11.0 \\
\hline 1993 & 27,739 & 2873 & 558.2 & 21.1 & 20.1 & 7.3 \\
\hline 1994 & 31,983 & 3324 & 699.7 & 247 & 21.9 & 6.6 \\
\hline 1995 & 34,778 & 3569 & 786.4 & 26.5 & 22.6 & 7.4 \\
\hline 1996 & 35,353 & 3571 & 835.0 & 29.2 & 23.6 & 8.2 \\
\hline 1997 & 35,927 & 3815 & 932.2 & 10.2 & 25.9 & 10.2 \\
\hline 1998 & 35,485 & 3763 & 1029.2 & 42.2 & 29.0 & 11.2 \\
\hline 1999 & 35,884 & 3810 & 1593.4 & 67.7 & 44.4 & 17.8 \\
\hline 2000 & 38,428 & 3876 & 2157.6 & 93.1 & 56.1 & 24.0 \\
\hline 2001 & 41,559 & 3901 & 2585.8 & 97.6 & 62.2 & 25.0 \\
\hline 2002 & 43,042 & 3838 & 2822.7 & 92.3 & 65.6 & 24.0 \\
\hline 2003 & 43,016 & 3832 & 3094.6 & 88.8 & 71.9 & 23.2 \\
\hline 2004 & 42,533 & 3746 & 3420.6 & 94.7 & 80.4 & 25.3 \\
\hline 2005 & 42,415 & 3853 & 3661.2 & 96.1 & 86.3 & 24.9 \\
\hline 2006 & 43,150 & 4039 & 3972.8 & 107.3 & 92.1 & 26.6 \\
\hline 2007 & 43,410 & 4139 & 4198.9 & 122.4 & 96.7 & 29.6 \\
\hline 2008 & 42,446 & 4070 & 4327.8 & 132.7 & 102.0 & 32.6 \\
\hline 2009 & 41,906 & 3967 & 4298.6 & 128.4 & 102.6 & 32.4 \\
\hline 2010 & 41,524 & 3897 & 4290.8 & 117.2 & 103.3 & 30.1 \\
\hline 2011 & 40,965 & 3871 & 4315.9 & 120.9 & 106.3 & 31.0 \\
\hline
\end{tabular}

Table 3. Land stock of the Carpathian Region of Ukraine (2011).

\begin{tabular}{|c|c|c|c|c|c|c|c|c|}
\hline \multirow{3}{*}{$\begin{array}{l}\text { Administrative-territorial } \\
\text { unit }\end{array}$} & \multicolumn{3}{|c|}{ Total land area (thousand ha) } & \multicolumn{5}{|c|}{ Inclusive of land areas in farming enterprises } \\
\hline & \multirow{2}{*}{ Total } & \multicolumn{2}{|c|}{$\begin{array}{l}\text { Inclusive of agricultural } \\
\text { land area }\end{array}$} & \multirow{2}{*}{$\begin{array}{l}\text { Total agricultural lands } \\
\text { (thousand ha) }\end{array}$} & \multirow{2}{*}{$\begin{array}{l}\% \text { of total } \\
\text { land area }\end{array}$} & \multirow{2}{*}{$\begin{array}{l}\text { Total tillage } \\
\text { (thousand ha) }\end{array}$} & \multirow{2}{*}{$\begin{array}{l}\% \text { of total } \\
\text { tillage lands }\end{array}$} & \multirow{2}{*}{$\begin{array}{l}\text { Level of } \\
\text { plow-up. \% }\end{array}$} \\
\hline & & Total & Inclusive of tillage & & & & & \\
\hline Zakarpattia Oblast & 1275.3 & 454.3 & 200.6 & 13.0 & 2.86 & 11.5 & 5.7 & 88.5 \\
\hline Ivano-Frankivsk Oblast & 1392.7 & 633.5 & 374.4 & 25.0 & 3.94 & 23.5 & 6.3 & 94.0 \\
\hline Lviv Oblast & 2183.1 & 1269.7 & 797.7 & 55.0 & 4.33 & 49.7 & 6.2 & 90.4 \\
\hline Chernivtsi Oblast & 809.6 & 472.8 & 337.8 & 27.9 & 5.90 & 26.4 & 7.8 & 94.6 \\
\hline $\begin{array}{l}\text { Carpathian Region of } \\
\text { Ukraine }\end{array}$ & 5660.7 & 2830.3 & 1710.5 & 120.9 & 4.27 & 111.1 & 6.5 & 91.9 \\
\hline Ukraine & 60354.8 & 41722.2 & 32451.9 & 4345.9 & 10.42 & 4221.9 & 13.0 & 97.1 \\
\hline
\end{tabular}


branches. The same is true when we speak of the Carpathian Region of Ukraine. The increase of agrarian land average areas in farming enterprises is an important indicator of their development. It allows for the use of the advantages of big farming economies, since the size of land areas in agriculture is a basis for concentration of production.

Thus, the provision of optimal level of concentration of agricultural production on minor areas is among the most important problems of farming development encountered by majority of farmers in developed countries. Small, and, partially, mid-size farms are those that most commonly stand the hazard of bankruptcy, and the majority of such farms are marginally profitable. And that is what modifies a general trend of clustering.

Farmers in many cases are given worse lands: using $13 \%$ of tillable fields, they derive only $5 \%$ of agricultural production (in the aspect of economic branch- $-7.2 \%$ of crop and $1.8 \%$ of livestock product). However, in the Carpathian Region, they grow 22\% of regional agricultural production using $6.5 \%$ of tillage, thus proving higher efficiency of NRP use. Carpathian farmers' gross production in 2010 amounted to UAH 472.8 million (USD 75.0 million), which is $9.5 \%$ out of all farmers' outcome on a national level. The highest volume of gross output was with farmers of the Lviv Oblast-UAH 338.7 million (USD 53.8 million); this oblast, by the way, is the only one in the region where livestock product $(78.9 \%)$ forms the majority in the gross output. The farmers of the Chernivtsi Oblast added UAH 60.6 million (USD 9.6 million) to the regional gross output, with $83.8 \%$ of crop product; those of the Ivano-Frankivsk Oblast-UAH 38.2 million (USD 6.1 million), with $75.4 \%$ in the form of crop product; and the Zakarpattia Oblast contributed UAH 35.3 million (USD 5.6 million) where $55 \%$ was represented by crop product.

\section{Conclusions}

Assessment of nature-resource potential of the territory is an important component to help plan agricultural activity and an essential means in execution of regional policy. Comparison of nature-resource potential's integral value and volume of gross output obtained by farming enterprises of the administrative oblasts of the Carpathian Region of Ukraine witnesses their complete correlation which is best expressed when comparatively analyzed with land resources.

Further development of farming in the Carpathian Region of Ukraine in the aspect of use of its nature-resource potential requires farms' mutual cooperation and integration as well as the same with other enterprises, that is, their inclusions into the system of agro-business on the basis of specialization and co-operation of production. In this case, farms with comparatively small land areas can also become profitable.

Land allotments' extension is also required in the form of land plots lease (safety fund, peasant's shares, etc.). The extension is possible by way of incorporation of bankrupt farms. Formation of farm's optimal land area together with the set of necessary means of production is pre-conditions to generation of commodity-competitive farming enterprise whose entrepreneurial activity would provide for gaining profit. The profit gained from product's sale would at least allow the farmer satisfy his family's consuming demands, and, as a maximum, let him execute extended reproduction and accumulation of capital.

We find it appropriate to recommend farmers majorly specialize in production of labor-intensive cultures (horticulture, vegeculture, viniculture) and some kinds of livestock growth (optimal land areas at this specialization are much less) and establishment of highly specialized enterprises engaged in bee-farming, fur farming, fish farming (where the land is required only as a spatial basis), etc.

\section{Debatable Issues}

Along with this, in the first turn, stabilization and certain reduction of farming economies in Ukraine (and its Carpathian Region) to 40 - 42 thousand can not but arouse concern, since it means less than 1 per 1000 inhabitants. On the one hand, such small amount of farms represents a present-day state of entrepreneurship development in Ukraine, on the other-it shows real conditions and capabilities of economic activity in Ukraine which depends upon a system of juridical, economic, management and lawmaking decisions.

Second, agricultural lands' excessive tillage in farming economies can not but call attention to and raise the question of whether gardening, winegrowing and cattle breeding development are possible in Ukraine.

Third, the questions as to farms' optimal size on the whole and in the Carpathian Region in particular are also debatable in Ukraine, e.g., to what extent can a 30 - 100 ha farm be economically efficient?

\section{REFERENCES}

[1] V. P. Rudenko, “Geography of Ukraine Natural Resource Potential,” Academy, Kyiv, Green Bucovina, Chernivtsi, 1999, 568 Pages.

[2] V. P. Rudenko, "The Geographical Diversity of Ukraine Natural-Resource Potential," Publishing House of the Krasnoyarsk Economic and Trade Institute, Krasnoyarsk, 2007, 168 Pages.

[3] V. A. Baranovsky, "Natural-Resource Potential. Scale 1:9000000," Ecological and Economic Balance of the Territory, Kyiv, 2005, 35 Pages.

[4] Natural Resource Potential of Ukraine Sustainable De- 
velopment,” In: B. Danilishin, S. Doroguntsov, V. Mishchenko, et al., Eds., Natural Resource Potential of Ukraine Sustainable Development, Council of Ukraine Productive Forces, Kyiv, 1999, 716 Pages.

[5] I. Yukhnovsky and G. Loboda, "Land Price,” Ukraine Governmental Courier, No. 105, 2002, p. 7.

[6] V. P. Rudenko and S. V. Rudenko, "Revaluation of Nature-Resource Potential of Ukraine,” Geography and Natural Resources, Vol. 32, No. 1, 2011, pp. 95-97.

[7] “Agriculture of Ukraine: Statistical Bulletin,” State Sta- tistics Committee of Ukraine, Kyiv, 2011, 262 Pages.

[8] P. Sabluk, "Agricultural Economics and Policy in Ukraine: Results of the Past and Look to the Future," Institute of Agrarian Economics, Kyiv, 2001, 428 Pages.

[9] V. Mesel-Veselyak, P. Sabluk, M. Malik, et al., "Forms of Economic Development in Rural Areas,” Harvest Publishing, Kyiv, 1993, 376 Pages.

[10] P. Makarenko, “Models of Agricultural Economics,” Institute of Agrarian Economics, Kyiv, 2005, 682 Pages. 